\title{
Evaluation of Additive/Synergistic Effect of Piper nigram and Ocimum sanctum Extracts for their Antidepressant Activity
}

\author{
K. Mohana Rao, B. Siva*, U. Mahendra, K. Vinay, A. Narendra Babu, J.Naga Lakshmi \\ Department of Pharmacology, Chalapathi Institute of Pharmaceutical Sciences, Guntur, AP, India. \\ *Corresponding author's E-mail: sivanayakbhukya6@gmail.com
}

Received: 19-07-2021; Revised: 21-09-2021; Accepted: 28-09-2021; Published on: 15-10-2021.

\begin{abstract}
Depression is a state of excessive sensitivity to criticism, fear of rejections, lack of self-interest, loss of pleasure. In the traditional systems of medicine, many plants and formulations have been used to treat depression for thousands of years. In recent times, research on the plants increased globally and so many plants provide the evidence to cure diseases. Ocimum sanctum, popularly known as Tulsi is one of the sacred herbs for Hindus in the Indian subcontinent. It has a versatile role in traditional medicine. The fruits of Piper nigrum are used to make black pepper. This hotly pungent spice is one of the earliest known and most widely used spices in the world today. Wide range of animal tests for antidepressant agents are commonly used. The Forced swim test and Tail suspension test in mice were mostly used. Hence in the present study Forced swim test was used as animal model of depression. In present study immobility time in Forced swim test was significantly decreased by a combination of Piper nigrum fruit extract and Ocimum sanctum extract treated groups compared to control group. The combination of extracts (50 mg/kg each) activity was comparable to standard drug Fluoxetine. Treatment with extracts does not modify the locomotor activity of mice, which indicates that they exert antidepressant effects without modifying significantly locomotor activity. Therefore, the present study confirms the combination of alcoholic extract of Piper nigrum (AEPN) fruit and aqueous extract of Ocimum sanctum (AEOS) possessing additive/synergistic antidepressant activity.
\end{abstract}

Keywords: Depression, Ocimum sanctum, Piper nigrum, Forced swim test, Tail suspension test, immobility, antidepressant.

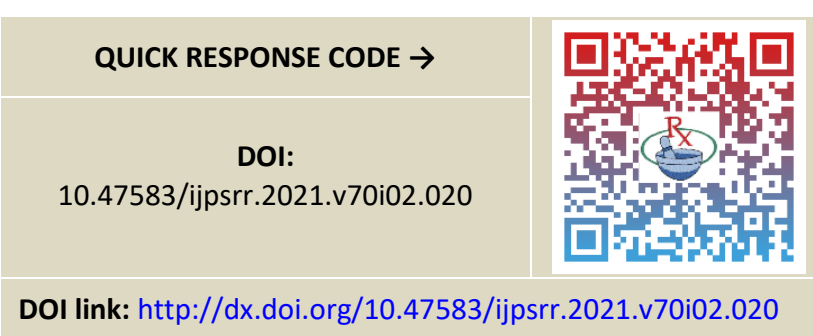

\section{INTRODUCTION}

$\mathrm{D}$ epression is a serious condition as characterized by the World Health Organization (WHO) as one of the most disabling disorders in the world. The global burden of disease predicts that depression is the secondleading origin of disability in 2020. $\frac{1}{\text { Several mental }}$ disorders of depression including loss of interest, sadness, low appetite, feelings of guilt, disturbed sleep, low concentration, and others. ?

The pathophysiology of persistent depressive disorder and depression continues to be a major area of research. The brain chemistry of mood is affected by a complicated interplay between neurotransmitters and receptors. While serotonin is the most commonly implicated neurotransmitter and the target of pharmaceutical intervention, additional neurotransmitters such as dopamine, epinephrine, norepinephrine, GABA, and glutamate have been linked to $\operatorname{mood}^{3,4,5}$. There are various synthetic drugs used for the treatment of depression based on their mechanism of actions. They are, selective serotonin reuptake inhibitors (SSRIs - fluoxetine), serotonin-noradrenalin reuptake inhibitors (SNRIs duloxetine), noradrenaline and specific serotonergic antidepressants (NASSAs - mirtazapine), tricyclic antidepressants (TCAs -amitriptyline) and monoamine inhibitors (MAOls - tranylcypromine) Loss of libido, tolerance, physical dependence and insomnia is associated with selective serotonin $(5-\mathrm{HT})$ reuptake inhibitors and tricyclic antidepressants, several drug-drug interactions may occur ${ }^{6}$.

Black pepper (Piper nigrum) and Tulasi (Ocimum sanctum) have the antidepressant activity. Black pepper is also known as the king of spices basically originated from the Western Ghats. It is the most exported spice in India, India accounts an average of more than 70 percent of total production. Piper nigrum contain various chemical constituents includes Piperine, piperidine, piperidone, piperidone, Guinee sine and piperamide, as well as $2-4 \%$ volatile oils containing safrole. ${ }^{7}$ Piper nigrum has been experimentally proved as to cure constipation, diahorrea and also for spasmodic effects ${ }^{8}$, antioxidant effect ${ }^{9}$, anticarcinogenic activity $^{10}$, seizure disorders ${ }^{11,12}$, antiinflammatory and analgesic activity ${ }^{13}$, cognitive disorders ${ }^{14}$.

Ocimum sanctum (Tulsi) has been used successfully in the treatment and prevention of many stress disorders ${ }^{15}$. Ocimum sanctum Linn, belongs to the family Labiatae popularly known as Tulsi in Hindi and Holy Basil in English ${ }^{16}$. Tulsi has been recognised for thousands of years to be one of India's greatest healing herbs. Tulsi in Sanskrit 
means "one that is incomparable". It enhances general health and wellbeing, having positive overall effects on the body and mind ${ }^{15}$. Ocimum sanctum is known to possess various therapeutic properties, and mentioned as one of the most noteworthy plant in various medicinal systems. Ocimum sanctum has been reported to possess anticarcinogenic ${ }^{17}$, antidiabetic ${ }^{18}$, antihelminthic ${ }^{19}$, antiinflammatory $^{20}$, antioxidative ${ }^{21}$, antibacterial ${ }^{22}$, antistress ${ }^{23}$, and antiulcer ${ }^{24}$ properties. Ocimum sanctum leaves contain $0.7 \%$ volatile oil comprising about $71 \%$ eugenol and $20 \%$ methyl eugenol. Additional components are carvacrol, sesquiterpine hydrocarbon caryophyllene, apigenin, luteolin, ocimumosides $A$ and $B$, ocimarin, apigenin-7-O-glucuronide, orientin, olludistin, and ursolic $\operatorname{acid}^{23}$.

Keeping in view of wide range of therapeutic importance of Ocimium sanctum and Piper nigrum, the present study was undertaken to investigate the synergistic/additive anti-depressant effect of combination of Ocimium sanctum and Piper nigrum in albino mice using Force swim test as animal model. Fluoxetine is used to standardise the animal models of depression.

\section{MATERIALS AND METHODS}

\section{Plant material}

The plant materials consist of dried powdered leaves and fruits of Ocimium sanctum and belonging to the family Labiatae and dried powdered fruits Piper nigrum belonging to the family Piperaceae.

\section{Preparation of plant extract}

a) Fresh leaves of Ocimum sanctum. were collected, shade dried and coarsely powdered. The powder was extracted with solvent like water by Soxhlation method, then the extracted solvent was filtered and filtrate was concentrated using a Rota Evaporator.

b) Dried fruits of Piper nigrum (Black pepper) were collected, and coarsely powdered. The powder was extracted with solvent like alcohol by Soxhlation method, then the extracted solvent was filtered and filtrate was concentrated using a Rota Evaporator.

\section{Preliminary Phytochemical Screening}

The aqueous extract of Ocimum sanctum (AEOS) and alcoholic extract of Piper nigrum (AEPN) were screened for the presence of various phytoconstituents like steroids, alkaloids, glycosides, flavonoids, carbohydrates, proteins and phenolic compounds ${ }^{25}$.

\section{Experimental Animals}

Healthy adult mice of either sex, weighing around 25-30g were selected in the present study. The experimental protocol was priorly approved by the Institutional Animal Ethics Committee (IAEC) of Chalapathi Institute of Pharmaceutical Sciences, Guntur, Andhra Pradesh (Reg.No. 1048/PO/Re/S07/CPCSEA). Animals were randomly housed in groups of five in polypropylene cages at an ambient temperature of $25 \pm 1^{\circ} \mathrm{C}$ and $45-55 \%$ relative humidity, with a $12 \mathrm{~h}$ light/dark cycle. The animals had free access to standard pellet and water ad libitum.

\section{Antidepressant Activity}

The mice were divided into five groups $(n=5)$. Drugs and vehicle were administered to the animals $60 \mathrm{~min}$ prior to study.

Group-I (Vehicle control): Mice were administered Sod. CMC (2 ml/kg) orally.

Group-II (Standard group): Mice were administered standard drug Fluoxetine (10 mg/kg orally).

Group-III (AEOS, $100 \mathrm{mg} / \mathrm{kg}$ ): Mice were administered Ocimum sanctum leaves extract $(100 \mathrm{mg} / \mathrm{kg}$ )

Group-IV (AEPN, $100 \mathrm{mg} / \mathrm{kg}$ ): Mice were administered Piper nigrum fruit extract $(100 \mathrm{mg} / \mathrm{kg})$

Group-V [AEOS (50 mg/kg) + AEPN (50 mg/kg)]: Mice were administered Ocimum sanctum leaves extract $(50 \mathrm{mg} / \mathrm{kg}$ ) and Piper nigrum fruit extract $(50 \mathrm{mg} / \mathrm{kg}$ )

\section{Forced Swim Test ${ }^{26}$}

A depressed state can be induced in mice by forcing them to swim in a narrow cylinder. For the forced swim test (FST), mice of either sex were individually forced to swim in an open cylindrical container $(20 \mathrm{~cm}$ height, $10 \mathrm{~cm}$ diameter) containing $19 \mathrm{~cm}$ of water at $25 \pm 1^{\circ} \mathrm{C}$. Treatment was given $60 \mathrm{~min}$ prior to study. All animals were forced to swim for $6 \mathrm{~min}$ and the duration of immobility was observed and measured during the final 4 min interval of the test. Each mouse was judged to be immobile when it ceased struggling and remained floating motionless in the water, making only those movements to keep its head above water. A decrease in the duration of immobility is indicative of an antidepressant like effect.

\section{Statistical analysis}

The results are expressed as mean \pm standard error of means (S.E.M.). The data of anti-depressant results were statistically analyzed by One-way analysis of variance (ANOVA) followed by Bartlett's test using graph pad prism version 6.0.

\section{RESULTS AND DISCUSSION}

\section{Physicochemical analysis}

The AEOS and AEPN were subjected to preliminary phytochemical screening using standard procedures.

The phytochemical screening of AEOS revealed the presence of Alkaloids, Glycosides, Tannins, Flavonoids and while AEPN possess Steroids, Carbohydrates, Alkaloids, Saponins, Triterpenoids as phytochemical constituents (Table-1).

The anti-depressant activity was evaluated by performing forced swim test. Healthy adult albino mice weighing 2530 gms were selected for the study. The animals allowed to swim. 
Table 1: Phytoconstituents present in AEOS and AEPN

\begin{tabular}{|c|l|c|c|}
\hline S.No & \multicolumn{1}{|c|}{ Phytoconstituent } & AEOS & AEPN \\
\hline 1 & Steroids & & \\
\hline & a) Salkwoski test & + & - \\
\hline & b) Liebermann buchard's test & + & - \\
\hline
\end{tabular}

\section{Carbohydrates}
a) Molish's test
b) Benedict's test

3 Proteins
a) Biuret test
b) Million's test
c) Ninhydrin test

4 Alkaloids
a) Mayer's test
b) Dragondroff's test
c) Wager's test
d) Hager's test

5 Glycosides
a) Brontrager's test
b) Modified Brontrager's test
c) Baljet test

6 Saponins
a) Foam test

7 Tannins
a) Ferric chloride test
b) Lead acetate test

8 Flavonoids
a) Shinoda test
b) Zinc hypochloride test

9 Triterpenoids
a) Salkwoski test
b) Liebermann buchard's test

$(+)$-indicates presence; $(-)$ - indicates presence

Table 2: Effect of AEOS and AEPN on Immobility Period in Forced Swim test

\begin{tabular}{|c|c|c|c|}
\hline S.No & Drug & $\begin{array}{c}\text { Dose } \\
\text { (mg/kg) }\end{array}$ & $\begin{array}{c}\text { Immobility } \\
\text { Period (sec) }\end{array}$ \\
\hline 1 & Control & $2 \mathrm{ml} / \mathrm{kg}$ & $168.4 \pm 0.51$ \\
\hline 2 & Fluoxetine & 10 & $131 \pm 1.58 * * * *$ \\
\hline 3 & AEOS & 100 & $149 \pm 0.89$ \\
\hline 4 & AEPN & 100 & $154.8 \pm 0.37$ \\
\hline 5 & AEOS + AEPN & 50 & $128.2 \pm 2.13^{* * * *}$ \\
\hline
\end{tabular}

Each value represents Mean \pm S.E.M., $n=5 . * * * * p<0.0001$ compared with control.

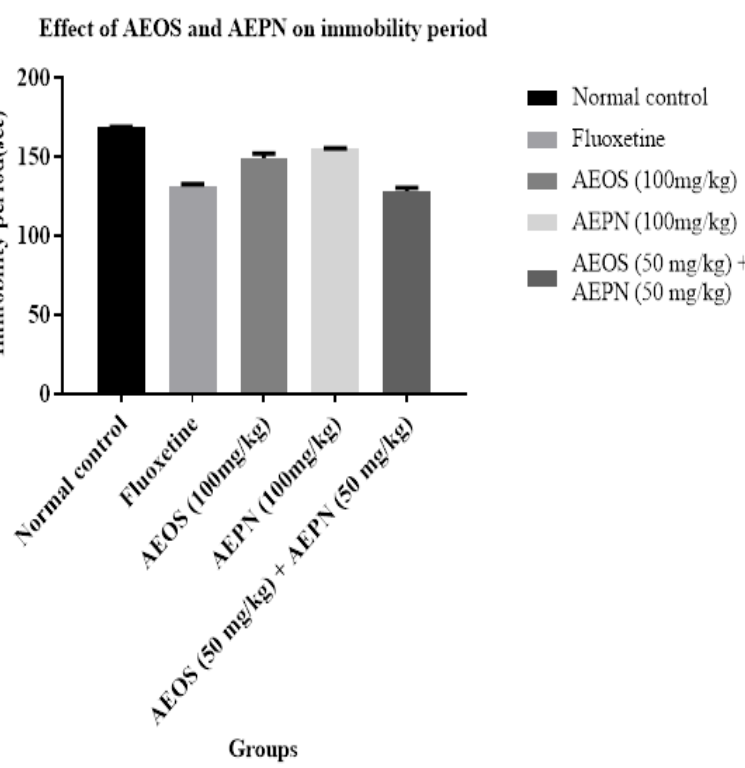

Figure 1: Effect of AEOS and AEPN on Immobility Period in Forced Swim test

Fluoxetine $(10 \mathrm{mg} / \mathrm{kg}) 131 \pm 1.58(\mathrm{p}<0.0001)$ compared to control group $168.4 \pm 0.51$. While AEPN (100 mg/kg) and AEOS $(100 \mathrm{mg} / \mathrm{kg})$ treated animals exhibited significant reduction in immobility period $154.8 \pm 0.37,149 \pm 0.89$ respectively. While the combination of AEPN $(50 \mathrm{mg} / \mathrm{kg}$ ) and AEOS $(50 \mathrm{mg} / \mathrm{kg}$ ) reduced immobility time in animals predominantly comparable with that of standard drug is $128.2 \pm 2.13(p<0.0001)$. Hence the combination of AEPN and AEOS produced synergistic or additive effect.

\section{CONCLUSION}

The experimental study concluded that the ethanolic extracts of Piper nigrum (AEPN) and aqueous extracts of Ocimum sanctum (AEOS) in combination shows the predominant anti-depressant activity compared to individually treated with AEPN, AEOS and standard drug Fluoxetine. Therefore, the combination of both extracts exhibited synergistic/additive effect.

\section{REFERENCES}

1. N. Bohra, S. Srivastava, M. Bhatia. Depression in women in Indian context. Indian J Psychiatr. 2015; 57 (7): 239-245.

2. H. Anisman, R.M. Zacharko. Depression: the predisposing influence of stress. Behav Brain Sci. 1982; 5 (1): 89-99.

3. Duman RS, Heninger GR, Nestler EJ. A molecular and cellular theory of the depression. Arch Gen Psychiati. 1997; 54(7):597-606.

4. Thase ME. Molecules that mediate mood. N Engl J Med. 2007; 357(23):2400-2402.

5. Nutt DJ, Baldwin DS, Clayton $A H$, Elgie R, Lecrubier $Y$, Montejo AL, Papakostas GI, Souery D, Trivedi MH, Tylee A. Consensus statement and research needs: the role of dopamine and norepinephrine in depression 
and antidepressant treatment. J Clin Psychiatry. 2006; 67 (Suppl 6):46-49.

6. https://www.wikidoc.org/index.php/Antidepressants \#Types of Antidepressants.

7. G. Srinivas Rao, Swamy Charan D, V. Ananth Kumar, D. Sandeep Reddy, R. Bhargav Raju. Antidepressant activity of Piper nigrum fruit extract and comparison with Imipramine in mice models. Journal of Pharmacy Research. 2012; 5(7): 3910-3912.

8. Mehmood MH, Gilani AH; Pharmacological basis for the medicinal use of black pepper and piperine in gastrointestinal disorders; Available online at www.ijpras.com 21 Journal of Medicinal Food. 2010; 13(5):1086-96.

9. Ramnik singh, Narinder Singh, B.S Saini, Harwinder Singh Rao; In vitro antioxidant activity of pet ether of black pepper; Indian Journal of Pharmacology; 2008; 40(4):147-151.

10. Nalini N, Manju V, Menon VP; Effect of species on lipid metabolism in 1,2- dimethylhydrazine induced rat colon carcinogenesis; Journal of Medicinal Food; 2006; 9(2): 237-45.

11. Lee,S.A., Hong,S.S., Han,X.B,. Hwang,J.S., Oh, G.J.,Lee, K.S.,Lee,M.K., Hwang,B.Y. and Ro, J.S.; Piperine from fruits of Piper nigrum with inhibitory effect on monoamine oxidase and antidepressant-like activity; Chemical and Pharmaceutical Bulletin. 2005; 53: 832835.

12. Li,S., Wang C,Wang, M.,Li, W., Matsumoto, K. And Tang, Y.; Antidepressant like effects of piperine in chronic mild stress treated mice and its possible mechanisms; Life Sciences; 2007; 80: 1373-1381.

13. Gupta SK, Bansal P, Bhardwaj RK, Velpandian T; Comparative anti-nociceptive, anti-inflammatory and toxicity profile of nimesulide vs nimesulide and piperine combination; Pharmacology Research; 2000; 41(6):657-62.

14. Aroonsri Priprem, Pennapa Chonpathompikunlert, Saengrawee Sutthiparinyanont, Jintanaporn Wattanathorn; Anti-depressant and cognitive activities of intranasal Piperine -encapsulated liposomes; Advances in Bioscience and Biotechnology; 2011; 2: 108-116.
15. Dr. Narendre Singh, Dr. Yamuna Hoette, Dr. Ralph Miller. Tulsi: The Mother Medicine of Nature. International Institute of Herbal Medicine (Lucknow, India): 2002.

16. 4. Nadkarni K M. Indian Materia Medica. Popular Prakashan Pvt. Ltd., Bombay 1993, 1: 865-866.

17. Karthikeyan K, Gunasekaran P, Ramamurthy N, Govin dasamy S. Anticancer activity of Ocimum sanctum. Pharm Biol. 1999; 37:285-290.

18. Gupta S, Mediratta PK, Singh S, Sharma KK, Shukla R. Antidiabetic, anti-hypercholester-olaemic and antioxidant effect of Ocimum sanctum (Linn) seed oil. Indian J Exp Biol. 2006; 44:300-304.

19. Asha MK, Prashanth D, Murali B, Padmaja R, Amit A. Anthelmintic activity of essential oil of Ocimum sanctum and eugenol. Fitoterapia. 2001; 72:669-670.

20. Godhwani S, Godhwani JL, Vyas DS. Ocimumsanctum: an experimental study evaluating its antiinflammatory, analgesic and antipyretic activity in animals. J Ethnopharmacol. 1987; 21:153-163.

21. Geetha RK, Vasudevan DM. Inhibition of lipid peroxidation by botanical extracts of Ocimum sanctum: in vivo and in vitro studies. Life Sci. 2004; 76:21-28.

22. Singh S, Malhotra M, Majumdar DK. Antibacterial activity of Ocimum sanctum L. fixed oil. Indian J Exp Biol. 2005; 43:835-837.

23. Gupta P, Yadav DK, Siripurapu KB, Palit G, Maurya R. Constituents of Ocimum sanctum with antistress activity. J Nat Prod. 2005; 70:1410-1416.

24. Dharmani P, Kuchibhotla VK, Maurya R, Srivastava S, Sharma S, Palit G. Evaluation of anti-ulcerogenic and ulcer-healing properties of Ocimum sanctum Linn. J Ethnopharmacol. 2004; 93:197-206.

25. Kokate, C.K (1986). Preliminary phytochemical analysis. In: Kokate CK (eds). Practical Pharmacognosy. 1st ed. New Delhi: Vallabh Prakashan, 111.

26. Porsolt, R.D., Bertin, A., Jalfre, M (1977). Behavioral despair in mice: a primary screening test for antidepressants. Arch Int Pharmacodyn Ther. 229:327-36.

Source of Support: The author(s) received no financial support for the research, authorship, and/or publication of this article.

Conflict of Interest: The author(s) declared no potential conflicts of interest with respect to the research, authorship, and/or publication of this article.

For any question relates to this article, please reach us at: editor@globalresearchonline.net New manuscripts for publication can be submitted at: submit@globalresearchonline.net and submit_ijpsrr@rediffmail.com 